\title{
South Africa's Youth Unemployment Dilemma: Whose Baby is it anyway?
}

\author{
Natanya Meyer \\ Faculty of Economic Science and IT, North-West University, VTC, South Africa \\ Natanya.meyer@nwu.ac.za
}

\begin{abstract}
Youth unemployment is a major concern to various different countries, including South Africa, which ranked fourth-worst in the global youth unemployment ratings in 2013 and 2014reaching rates of more than 50 percent. Entrepreneurship development and increased employability through appropriate skills development have been considered as possible solutions to this growing problem. The aim of this study is to determine perceptions of students pertaining their entrepreneurial outlook and perceived employability. Validated Entrepreneurship- and Employability Scales were used to determine entrepreneurial outlook and perceived employability perception. A total of 293 students from a South African University participated in this study. Data were analyzed using descriptive statistics, histograms, Pearson correlation, MANOVA and ANOVA. The findingsof this studyshow that student'sperceptions indicated that if they haveamore entrepreneurial outlook, it could strongly increase their employability. They also do not think that after the completion of their degrees that they would be more employable. A significance difference was found between year level of study, race, age, and perception of entrepreneurial outlook and employability variables of the students.They seem to have a realistic view when it comes to the risk of possible unemployment for some time after graduation. Based on these findings, it is suggested that introducing entrepreneurship training and employability programs (skills development) to students during the completion of their higher education career, could assist in the reduction of youth unemployment in South Africa.
\end{abstract}

Keywords: Youth unemployment, entrepreneurship, employability, training, students, South Africa

\section{Introduction}

"We cannot always build the future for our youth, but we can build our youth for the future." These wise words were expressed by President Franklin D. Roosevelt (Wise-Quote, 2016). In a country, such as South Africa, where more than half of its youth are actively seeking formal employment, it is even more important to invest in their future. Globally, the creation of employment opportunities has been a challenge, and South Africa is experiencing this pressure first-hand. The overall unemployment rate in South Africa is currently at 27.1 percent (Stats SA, 2016), which is more than three times the global average ofeight percent (CIA World Fact Book, 2016). The youth unemployment rate sketches an even more discouraging picture. According to Statistics South Africa (2016), South Africa's youth (aged 15-24) unemployment rate stood at 54.5 percent, as shown in the 2016third quarter labor force data. This is more than double that of the total unemployment rate (27.1\%). South Africa's youth unemployment rate is calculated as being almost four times that of the subSaharan Africa average (Kane-Berman, 2015). These rates are calculated according to the strict definition of unemployment and include only people who are actively seeking employment but without success. When using the expanded definition of unemployment, including all those desiring employment regardless of whether or not they are actively trying to obtain it, these figures rise significantly (Reserve Bank, 2015). Globally, approximately 73.4 million youths are unemployed according to International Labor Organization (ILO) (ILO, 2016). With approximately 1.38 million youths unemployed, South Africa accounts for 1.9 percent of the global youth unemployment rate, but only 0.77 percent of the world's youth population (Kane-Berman, 2015). At the very least, this is a dismal picture that requires urgent intervention. Businesses that would be able to create a substantial quantity of job opportunities over the next five to ten years are urgently needed. Conversely, large national and multi-national businesses, such as Arcelor Mittal and Sasol Limited, are shedding rather than creating jobs. The government is economically inefficient and ineffective when it comes to job creation (Mmesi, 2015). As small to medium-sized businesses create most jobs in the economic context, entrepreneurship could aid towards alleviating the problem (OECD, 2015). This article focuses on the perceptions of a group of students regarding unemployment and the possibility that entrepreneurship training and employability programs might be a solution to the rising issue of youth unemployment. 


\section{Literature Review}

South Africa's unemployment at a glance: South Africa is currently the tenth worst performer globally regarding unemployment, with a 25.5 percent 2016 predicted unemployment rate (ILO, 2016). According to Statistics South Africa's first quarter, actual figures already exceed this prediction at 27.1 percent (Stats SA, 2016). Table 1 reflects the ten countries with the highest unemployment rates.

Table 1: Global highest unemployment rates (2016 projections)

\begin{tabular}{lll}
\hline Ranking & Country & Unemployment Rate (\%) \\
\hline 1 & Djibouti & 53.0 \\
2 & Solomon Islands & 34.9 \\
3 & Mauritania & 31.1 \\
4 & Reunion & 30.0 \\
5 & Gambia & 29.9 \\
6 & Bosnia and Herzegovina & 29.4 \\
7 & Macedonia, FYR & 28.1 \\
8 & Lesotho & 28.0 \\
9 & Guadeloupe & 26.4 \\
$\mathbf{1 0}$ & South Africa & $\mathbf{2 5 . 5}$ \\
\hline
\end{tabular}

Source: ILO, 2016

Table 2 indicates a summary of the South African unemployment rates from 1994. This period was chosen as 1994 was the first democratic elections after many years of apartheid. During this period unemployment rates have been as low as 16.9 percent and as high as 27.2 percent.

Table 2: South Africa's unemployment rates: 1994 - 2015

\begin{tabular}{llllll}
\hline Year & $\begin{array}{l}\text { Unemployment } \\
\text { Rate (\%) }\end{array}$ & Global Ranking & Year & $\begin{array}{l}\text { Unemployment } \\
\text { Rate (\%) }\end{array}$ & Global Ranking \\
\hline 2016 & 25.5 & $10^{\text {th }}$ & 2004 & 24.7 & $10^{\text {th }}$ \\
2015 & 25.0 & $8^{\text {th }}$ & 2003 & 27.1 & $8^{\text {th }}$ \\
2014 & 25.1 & $9^{\text {th }}$ & 2002 & 27.2 & $7^{\text {th }}$ \\
2013 & 24.6 & $9^{\text {th }}$ & 2001 & 25.4 & $8^{\text {th }}$ \\
2012 & 25.0 & $7^{\text {th }}$ & 2000 & 26.7 & $9^{\text {th }}$ \\
2011 & 24.7 & $6^{\text {th }}$ & 1999 & 25.4 & $9^{\text {th }}$ \\
2010 & 24.7 & $6^{\text {th }}$ & 1998 & 25.0 & $10^{\text {th }}$ \\
2009 & 23.7 & $8^{\text {th }}$ & 1997 & 22.9 & $4^{\text {th }}$ \\
2008 & 22.7 & $9^{\text {th }}$ & 1996 & 21.0 & $6^{\text {th }}$ \\
2007 & 22.3 & $10^{\text {th }}$ & 1995 & 16.9 & $18^{\text {th }}$ \\
2006 & 22.6 & $12^{\text {th }}$ & 1994 & 20.0 & \\
2005 & 23.8 & $9^{\text {th }}$ & & &
\end{tabular}

Source: Business Tech, 2015

After the record low rate experienced in 1995, the rate rose steadily until 2002, when it began to decrease again. At the current rate of 27.1 percent, South Africa is moving towards its 2002 peak again and urgent recommendations and solutions to stop the further rise in unemployment rates are required. Daniel (2013) lists the causes of unemployment in Africa as a lack of quality education systems and training facilities, along with poor leadership. In addition, Kirk (2010) lists the following causes namely, the mismatch of abundant non-skilled labor, a declining learnership previously known as apprenticeship training which should be enhancing transferable skills, minimum wages and over-protective labor laws, making it risky and unattractive for companies to hire new employees. Other causes can be linked to the legacy of apartheid, changes in the demand and supply of labor, the lingering effects of the 2008/2009 recession, the part trade unions play and a general lack of interest in entrepreneurship (Department of Government Communication and Information Systems, 2015).The youth unemployment picture is even more dismal. The ILO describes this issue as being that of a generation at risk (ILO, 2013), while the Economist refers to the 'lost generation' (Economist, 2013). South Africa currently has a youth unemployment rate of 54.5 percent (aged 15-24). This 
is the age group of youths between 15 and24 years and is most commonly specified in reports by the ILO, the World Bank, and the World Economic Forum. Table 3 indicates South Africa's youth unemployment position in comparison with the ten countries having the highest youth unemployment rates. These figures are based on those for the age group 15 to 24 years.

Table 3: Global highest youth unemployment rates as at 2012, 2013 and 2014 estimates

\begin{tabular}{|c|c|c|c|c|c|c|}
\hline & 2012 & & 2013 & & 2014 & \\
\hline Rank & Country & $\begin{array}{l}\text { Unemploy- } \\
\text { ment Rate } \\
\text { (\%) }\end{array}$ & Country & $\begin{array}{l}\text { Unemploy- } \\
\text { ment Rate } \\
\text { (\%) }\end{array}$ & Country & $\begin{array}{l}\text { Unemploy- } \\
\text { ment Rate } \\
(\%)\end{array}$ \\
\hline 1 & $\begin{array}{l}\text { Bosnia and } \\
\text { Herzegovina }\end{array}$ & 62.8 & $\begin{array}{l}\text { Bosnia and } \\
\text { Herzegovina }\end{array}$ & 60.4 & Spain & 57.9 \\
\hline 2 & Kosovo & 55.3 & Greece & 58.4 & $\begin{array}{l}\text { Bosnia and } \\
\text { Herzegovina }\end{array}$ & 57.3 \\
\hline 3 & Macedonia & 53.9 & Spain & 57.3 & Greece & 53.9 \\
\hline 4 & Spain & 53.2 & South Africa & 53.6 & South Africa & 52.6 \\
\hline 5 & South Africa & 51.5 & Macedonia & 52.2 & Macedonia & 50.8 \\
\hline 6 & Serbia & 51.1 & Croatia & 51.5 & Serbia & 49.5 \\
\hline 7 & Guyana & $46.05^{*}$ & Libya & 51.2 & Libya & 48.9 \\
\hline 8 & Croatia & 43.1 & Serbia & 48.9 & Mauritania & 46.6 \\
\hline 9 & Tunisia & $42.3^{*}$ & Mauritania & 42.9 & Croatia & 45.9 \\
\hline 10 & Montenegro & 41.1 & Swaziland & 42.4 & Italy & 44.1 \\
\hline
\end{tabular}

* 2011 figures

Source: CIA, 2013; World Bank, 2014, World Bank 2015

Table 3shows that South Africa's youth unemployment problem has deteriorated, and has moved down one place globally from fifth worst in 2012 to fourth worst in 2013 and 2014. The reasons for youth unemployment are very similar to those relating to overall unemployment and include issues such as lack of qualifications and geographical unemployment. The latter focuses on youth unemployment in certain areas, such as cities, owing to the high volumes of rural-urban migration, cyclical unemployment caused by falling output during low economic conditions and frictional unemployment (Pettinger, 2012). Other contributing factors are cultural and social considerations, participation in the underground or the black/illegal economy and hysteresis, which refer to the mindset created by extended periods of unemployment. If young people have been unemployed for long periods of time, hysteresis may make them demotivated and uninterested in continuing the search for work opportunities (Webster, 2005). Poverty, corruption, the large population, entry of migrants and the stringent labor laws contribute further to this problem.

Young people, as our current generation, are facing a new set of challenges when it comes to obtaining employment (WEF, 2014). Many researchers, from both macro and micro-perspectives, have over the years pointed out possible causes for this phenomenon (Blanch flower \& Freeman, 2000; O'Higgins, 2001; Ryan, 2001, De Jongh et al., 2016). Mlatsheni and Rospabé (2002) state that some of the core macro-economic reasons for elevated levels of youth unemployment could include factors such as the geographic locality of these individuals, employer's requirements for experience and skills and the absence thereof in young people, and an oversupply of young job seekers in the market. Low levels of experience and high wage expectations also further contribute to this problem. Choudhry et al. (2013) refer to a situation called cyclical unemployment; this is when firms decide to rather dismiss young people with less experience during low economic periods and once again, this intensifies the youth unemployment problem. When viewed from a micro-economic perspective, the determinants of youth unemployment can be explained by differentiating between various theories:

- Mc Call's Job Search Theory - interprets youth unemployment by investigating the various strategies young people follow to identify jobs based on their preferences and reservations, especially concerning entry level wages (Mc Call, 1970);

- Job Matching Theory-investigates the level of how well young workers match the skills required from them by the employer. The bigger the match, the more probable the employment (Mortensen \& Pissarides, 1994); 
- The Human Capital Theory-has reference to the diverse levels of education and training as elements impacting on productivities, with bigger investment the chances of finding a job in these areas increases (Mincer, 1974).

Both micro- and macroeconomic causes contribute significantly to the number of young people finding it difficult to obtain employment in the South African labour market.Some inadequacies present in the South African labour market includes the caution of business owners to hire young people due to their possible lack of skills and level of employability (National Treasury, 2011) and the belief that entry level wages to young employees, in comparison to the risk they pose, are too high (Nattras \& Walker, 2005).

Entrepreneurship training and development as a possible solution: Entrepreneurship is considered to be a possibility to increased and sustained economic development and growth. This pertains particularly to developing countries with high poverty and unemployment rates (Kroon, 2002; Sivvam, 2012; Ambrish, 2014; Meyeret al., 2016). Therefore, investment in youth entrepreneurial programs is needed. Unfortunately, in some developing countries, corruption levels and other social issues are considered very high, and this could restrict funds aimed at enabling small business and entrepreneurship development and negatively affect these types of initiatives (Uddin \& Uddin, 2013; Odusegun, 2014). Entrepreneurship education both builds and shapes resilient entrepreneurs, and creates values, advances motivation and attitudes. It also supports the participants to acquire the necessary skills they may need for running a business or for work related employability (Bhat \& Khan, 2014).The importance of entrepreneurship as a contributing aspect in the growth and development of an economy has frequently been pointed out (Awashti \& Sebastian, 1996; Athayde, 2012). Developing countries, such as South Africa, should emphasize entrepreneurship training amongst the youth even more. Entrepreneurship training could offer opportunities for the youth to start small businesses and in turn help them to attain independence in the form of financial freedom (Raguž \& Matić, 2011). Ekpoh and Edet (2011) state that a positive relation exists between entrepreneurship education and attitudes. Therefore, entrepreneurship training and education could help students and young people develop a positive attitude and understanding regarding this topic (Bagheri \& Pihie, 2011).

Improving employability of youth as a possible solution: Those who do not intend to start a business ultimately would seek employment in the labor market. Therefore, the employability of young people are very important. Employability serves a prime economic purpose that is, achieving full employment (Forrier \& Sels, 2003). Employability can be defined as the personal aptitude to convey and complete work related tasks. It is the capability to complete an assortment of functions given by an employer (Forrier \& Sels, 2003; De Feyter et al., 2001). Heckman et al. (2006), Urzua (2009) and Ibarraran et al. (2014) state that employers value certain behaviors and attitudes linked to high productivity employees. Developing countries such as Latin America, Caribbean and the Dominican Republic have implemented youth training programs to raise participants' job skills and matching them to employers (Ibarraran et al., 2014). Results from these programs have been favorable. Another method to improve the employability of the youth is by introducing them into internships, learnerships/apprenticeship and skills programs. They can be defined as follow:

- An internship is a provisional position created within a business to provide learners or candidates with supervised 'on-the-job' training. Internships are usually for university graduates and students who are seeking some kind of experience in the labour market at an entry level. An intern can be paid and/or partly paid by thebusiness, but there is currently no regulations or rules surrounding this (W\&RSETA, 2016).

- A learnership can be defined as a structured learning programme in a scarce field of the economy or where there is a skills shortage. They are practical orientated and designed to address skills shortages and contribute towards unemployment (W\&RSETA, 2016).

- Skills programs are job-focused training interventions and are normally shorter learning programs. They also aid in skills capacity building in certain industries. They have a practical outlook and therefore greatly assist participants in improving their employability (W\&RSETA, 2016).

- Another form of technical training is apprenticeships. They differ from learnerships in that they are job and not career orientated as they are aimed at a specific trade such as for example, jewellery making (W\&RSETA, 2016).

For these programs to be successful, private sector support is required. Rolling out more employability programs in South Africa for the unemployed youth could have a positive impact on youth unemployment. 
Other factors that contribute to employability include career development, life and work experience, skills, confidence level, location, social class, gender and communication level in foreign languages amongst others (Karli, 2016). Qenani et al. (2014) reported that females found themselves almost 50 percent less employable than males. South Africa is a diverse cultural country with 11 official languages and El Mansour, and Dean (2016) highlight that being able to communicate in a foreign language is considered as an important employability skill.

\section{Methodology}

Sample: This study comprised a sample of first-, second-, third-year and postgraduate students from a university situated in the Gauteng province in South Africa. A non-probability convenience sample of approximately 350 students was drawn from the campus and 293 completed, and usable questionnaires were received. Questionnaires were completedvoluntarily, and no incentives were offered as encouragement to participate. The participants were assured of confidentiality, and no personal details were required in the questionnaire.

Development of the Research Instrument: A questionnaire instrument was developed in 2014 to test entrepreneurship and employability of students. The research instrument consisted of a biographical questionnaire, entrepreneurship scale and an employability scale. The biographical section of the questionnaire consisted of questions pertaining age, gender, race language, province, year of study, environment growing up in and whether one of the student'sparents were self-employed. The Entrepreneurship Scale developed by Meyer and Keyser (2017a) initially consisted of 12 items, but via discussion with professionals and co-researchers from Poland and the Netherlands, it was reduced to 7 items. A Cronbach Alpha coefficient of 0.73 was obtained for this scale. The 7 item scale was rated on a 6 point Likert Scale (1=strongly disagree up to 6 strongly agree). The scale consisted of questions such as: would you consider starting your own business, do you think that becoming an entrepreneur can reduce unemployment; did you get enough entrepreneurship practical and theoretical training during completion of your degree? The Employability Scale (Meyer\& Keyser, 2017b) consisted of 4items and was also rated on a 6 point Likert scale (1=strongly disagree up to 6 strongly agree). A Cronbach Alpha coefficient of 0.68 was obtained. The scale included questions such as: are you enthusiastic about finding the perfect job one day, do you become exited to start your job after completing your degree, do you want to find employment and having a degree will ensure that you easily find a job.

Statistical method: During the first phase of the data analysis, IBM SPSS version 23 was used to test for the construct validity of the Entrepreneurship- and Employability Scales. Before performing principal factor extraction, principal component extraction was done to determine the estimated number of factors, the presence of outliers and factorability of the matrices. The Eigen values and screen plot were studied to determine the number of factors involved. A principal axis factor analysis with a direct oblimin rotation was conducted to extract the factors (Tabachnick \& Fidell, 2001). During the second phase of the data analysis, the reliability of the items was determined by utilizing Cronbach Alpha coefficient. According to Nunnally (1967), the Cronbach Alpha coefficient values need to be above 0.6 to be acceptable. Furthermore, the Cronbach Alpha also provides information regarding which items of the instrument are related to each other and if any items need to change or be removed from the questionnaire (Pallant, 2007).

\section{Results and Discussion}

Biographical information of study population: The following section discusses the biographical information of the sample. Variablesincluding year of study, gender, age, race and province where students are residing were included.

Table 4 indicates that the bulk of the sample was $1^{\text {st }}$ and $2^{\text {nd }}$-year students $(70.9 \%)$. Females accounted for 56.2 percent of the sample and males 43.8 percent. South Africa is known for its racial distribution, and this also came about in the sample as 55.1 percent of the sample was African/Black, and 39.4 percent were White. The sample was not well represented by Indian/Asian and Coloured students. Most students were from the Gauteng Province (68.8\%) as this is the province the Universityis situated in. From the sample, 54.1 percent 
of students were between the age of 18 and 20 years. Other than these general demographic questions two questionspertaining the environment students grew up in were presented to the sample. The first question was where they grew up. There were two options 1) in a rural or informal area 2) in an urban or formal neighbourhood area. This question was asked to determine the context where the students grew up in. In some cases, people from rural areas are not as exposed to entrepreneurship as people from urban areas (Patel \& Chavda, 2013). From the sample, 81.5 percent of students grew up in a formal environment assuming that they most probably were exposed to some sort of entrepreneurial activity. Secondly, they were asked whether or not one of their parents were self-employed. More than half responded 'no'. This indicates that 64.7 percent of the sample did not have a parent entrepreneur figure to look up to while growing up. Growing up in an entrepreneurial environment might make someone more prone to start a business (Daley, 2013).

Table 4: Characteristics of participants

\begin{tabular}{|c|c|c|c|}
\hline Item & Category & Frequency & Percentage \\
\hline \multirow[t]{6}{*}{ Year level of study } & $1^{\text {st }}$ year & 101 & 34.6 \\
\hline & $2^{\text {nd }}$ year & 106 & 36.3 \\
\hline & $3^{\text {rd }}$ year & 69 & 23.6 \\
\hline & Post-graduate & 15 & 5.1 \\
\hline & Missing value & 1 & 0.3 \\
\hline & Total & 293 & 100 \\
\hline \multirow[t]{4}{*}{ Gender } & Male & 127 & 43.8 \\
\hline & Female & 164 & 56.2 \\
\hline & Missing values & 1 & 0.3 \\
\hline & Total & 293 & 100 \\
\hline \multirow[t]{6}{*}{ Race } & Coloured & 9 & 3.1 \\
\hline & Indian/Asian & 7 & 2.4 \\
\hline & White & 115 & 39.4 \\
\hline & African Black & 161 & 55.1 \\
\hline & Missing values & 0 & 0 \\
\hline & Total & 293 & 100 \\
\hline \multirow[t]{10}{*}{ Province } & Gauteng & 201 & 68.8 \\
\hline & Free State & 30 & 10.4 \\
\hline & Northern Cape & 18 & 6.2 \\
\hline & Mpumalanga & 16 & 5.5 \\
\hline & Eastern Cape & 7 & 2.4 \\
\hline & North-West & 8 & 2.7 \\
\hline & Kwazulu Natal & 5 & 1.7 \\
\hline & Limpopo & 3 & 1 \\
\hline & Missing values & 4 & 1.4 \\
\hline & Total & 293 & 100 \\
\hline \multirow[t]{5}{*}{ Age } & 18 - 20 years & 157 & 54.1 \\
\hline & 21 - 24 year & 128 & 43.9 \\
\hline & 25 years and older & 6 & 2 \\
\hline & Missing values & 1 & 0.3 \\
\hline & Total & 293 & 100 \\
\hline \multirow[t]{4}{*}{ Environment } & Rural & 52 & 17.8 \\
\hline & Urban & 238 & 81.5 \\
\hline & Missing values & 2 & 0.7 \\
\hline & Total & 293 & 100 \\
\hline \multirow{3}{*}{ Self-employed parent } & Yes & 103 & 35.3 \\
\hline & No & 189 & 64.7 \\
\hline & Total & 293 & 100 \\
\hline
\end{tabular}

Statistical Analysis: This section gives an overview of the descriptive statistics compiled from the sample. The mean, standard deviation, skewness, kurtosis and Cronbach Alpha are reported on for the two scales; Entrepreneurship and Employability. Histogramsreporting on the distribution of the two scales' scores as 
well as Pearson correlation is explained. ANOVA and MONOVA tests were conducted to determine if statistical differences between the groups exist. Table 5 describes the descriptive information for the sample.

Table 5: Descriptive statistics and Cronbach Alpha Coefficient

\begin{tabular}{llllll}
\hline Scale & Mean & SD & Skewness & Kurtosis & $\boldsymbol{\alpha}$ \\
\hline Entrepreneurship & 37.48 & 6.31 & -0.87 & 1.08 & 0.73 \\
Employability & 23.98 & 3.86 & -1.24 & 2.45 & 0.68 \\
\hline
\end{tabular}

The information seen in Table 5 indicates normal negative distribution scores for Entrepreneurship and Employability of students. Employability kurtosis is 2.45 and indicates a normal spread and distribution of the data. Acceptable Cronbach Alpha coefficients of 0.73 (Entrepreneurship Scale) and 0.68 (Employability Scale) were found. Hair et al. (1998) explain that generally the agreed lower limits for the Cronbach Alpha coefficient is 0.70 , but in the case of exploratory research, the Cronbach Alpha coefficient may be lowered to 0.60 .

Figure 1: Distribution of Employability scores scores

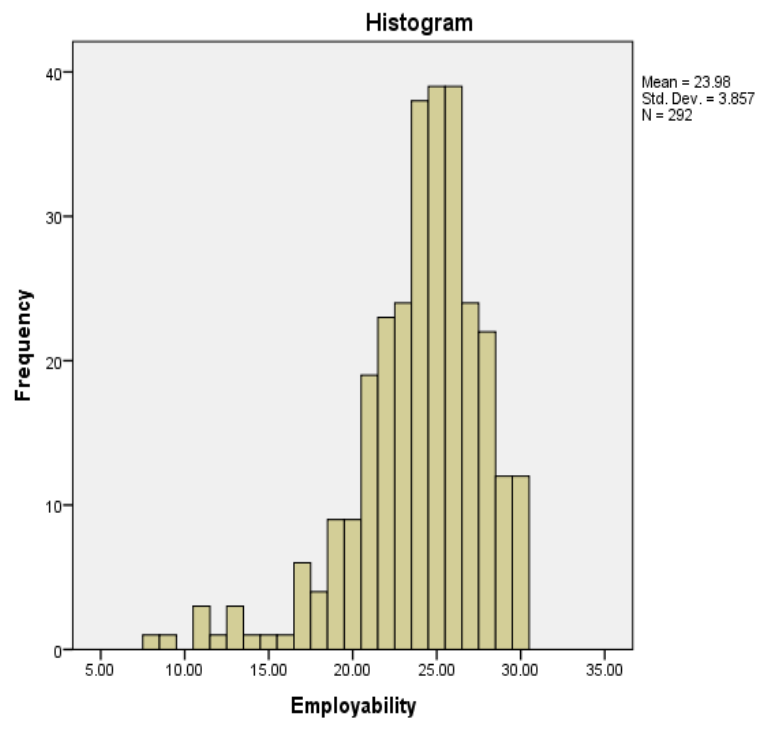

Figure 2: Distribution of Entrepreneurship

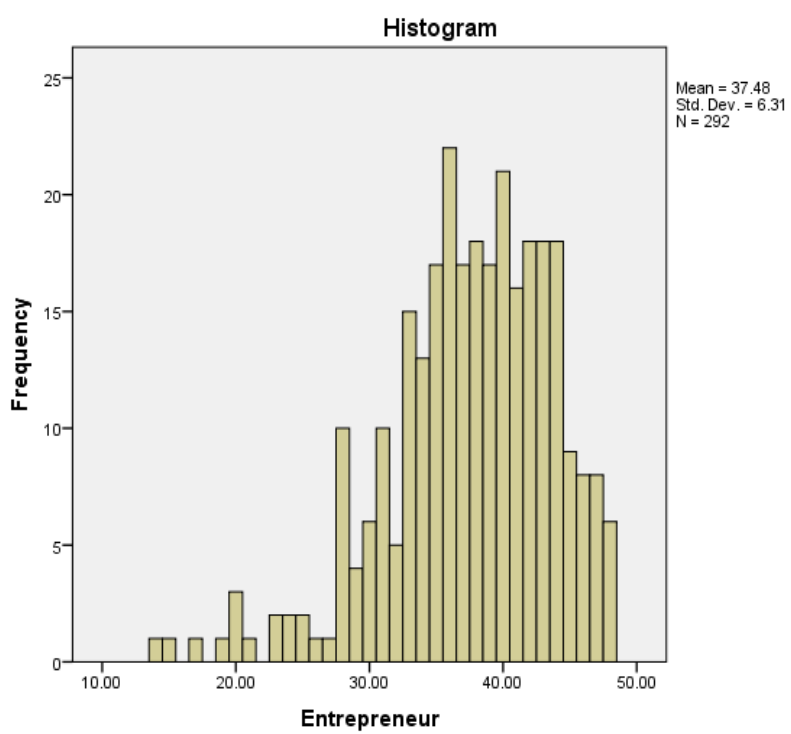

Figure 1 shows the mean scores for the Employability scale. The lowest score indicates that students do not think that after the completion of their degree that they would be employable. This isconcerning, and students clearly see the reality of being unemployed even after obtaining a degree. Graduate unemployment seems to be on the rise together with general unemployment and youth unemployment. Even though graduate unemployment only accounted for 5.9 percent of overall change in unemployment from 1996 to 2012, real unemployment for this group of the population has risen from 5.4 percent in 1995 to seven percent in 2012 (Oluwajoduet al., 2015).Figure 2 shows the mean scores for the Entrepreneurship scale rating given by subject in each of the five conditions, ranging from 1 strongly disagree to 6 strongly agree. The highest score indicates the extent to which the students experience, that if they become an entrepreneur, it will strongly decrease the unemployment rate. In this study, it can be concluded that the entrepreneurship scores seem to be suitable for parametric statistical analysis. Although a student might perceive that starting a business will reduce unemployment, there are many factors that need to be addressed before this maybecome a real solution to youth unemployment. Jones (2013) states that for youth entrepreneurship to really have an impact on youth unemployment levels, the government will have to build a stronger enabling environment for these entrepreneurs. One of the main barriers to successful youth-owned small businesses is South Africa' generally poor education system (Jones, 2013). Furthermore, the 2015/16 Global Entrepreneurship Monitor (GEM) reports that only 6.3 percent of people between the age of 18 and 24 years were engaged in Early-Stage Entrepreneurial Activity (TEA) during 2015 (Herrington \& Kew, 2016). This, 
combined with the results from the histogram in Figure 2, indicates that although students perceive that they can reduce the unemployment rate through entrepreneurship, the implementation and successfulness of this still needs much attention. Table 6 makes use of Pearson's correlation to determine if any significant correlation exists between certain individual characteristics, entrepreneurship and employability.

As seen from Table 6 a negative statistically significant relationship exists between the year level of study and the environment where students grew up. A practical negative relationship with a medium effect exists between year level of study, and a practical, positive effect exists with the year level of study and the age of the student. A negative statistically significant relationship exists between the race, province, having a selfemployed parent and entrepreneurship. In some cases, people from rural areas are not as exposed to entrepreneurship as people from urban areas (Patel \& Chavda, 2013). Growing up in an entrepreneurial environment might make someone more prone to also start a business (Daley, 2013).A practical significant relationship exists between the race of the student, and primary language spoken by the student (negative large effect). No relationship could be found between entrepreneurship outlook and employability of students. Multivariate Analysis of Variance (MANOVA) and Analysis of Variance (ANOVA) wasutilized to determine the significance of the difference between the dependent variables: entrepreneurship outlook and employability and the independent demographic variables of the sample.Demographic characteristics were analysed using Wilk's Lambda statistics, and the results are reflected in Table 7.

Table 6: Pearson correlations between Individual Characteristics, Entrepreneurship \& Employability

\begin{tabular}{|c|c|c|c|c|c|c|c|c|c|}
\hline Item & $\begin{array}{l}\text { Year level } \\
\text { study }\end{array}$ & Gender & Race & Province & Language & Age & $\begin{array}{l}\text { Enviro } \\
\text { nment }\end{array}$ & Parent & $\begin{array}{l}\text { Entrep } \\
\text { reneur } \\
\text { ship }\end{array}$ \\
\hline Year level of study & - & & & & & & & & \\
\hline Gender & -0.063 & - & & & & & & & \\
\hline Race & $-0.427^{* *}$ & -0.069 & - & & & & & & \\
\hline Province & 0.111 & 0.083 & $-0.244^{* *}$ & - & & & & & \\
\hline Language & $0.389^{* *}$ & 0.084 & $-0.859^{* *}$ & $0.310^{* *}$ & - & & & & \\
\hline Age & $0.610^{* *}$ & 0.024 & $-0.349^{* *}$ & $0.129^{*}$ & $0.326^{* *}$ & - & & & \\
\hline Environment & $-0.240^{* *}$ & -0.021 & $0.330^{* *}$ & $-0.153^{* *}$ & $-0.364^{* *}$ & $0.122^{*}$ & - & & \\
\hline $\begin{array}{l}\text { Parent self-employed } \\
\text { status }\end{array}$ & 0.075 & -0.015 & $-0.210^{* *}$ & -0.016 & $0.185^{* *}$ & 0.078 & $0.137^{*}$ & - & \\
\hline Entrepreneurship & 0.031 & 0.028 & $-0.164^{* *}$ & 0.084 & $0.151^{* *}$ & $0.121^{*}$ & -0.077 & 0.005 & - \\
\hline Employability & -0.066 & -0.093 & 0.109 & 0.049 & -0.092 & 0.086 & 0.060 & 0.064 & 0.081 \\
\hline
\end{tabular}

* Correlation is significant at the 0,05 level (2-tailed)

** Correlation is significant at the 0,01 level (2-tailed)

Table 7: MANOVA's differences in entrepreneurship and employability variables of demographic groups

\begin{tabular}{llllll}
\hline Variable & Wilks'Lambda & $\boldsymbol{F}$ & $\boldsymbol{D} \boldsymbol{f}$ & $\boldsymbol{P}$ & $\boldsymbol{\eta}^{\mathbf{2}}$ \\
\hline Year level of study & 0.920 & 4.040 & 6.00 & $0.001^{*}$ & 0.041 \\
Gender & 0.990 & 1.442 & 2.00 & 0.238 & 0.010 \\
Race & 0.941 & 2.976 & 6.00 & $0.007^{*}$ & 0.030 \\
Province & 0.951 & 1.015 & 14.00 & 0.436 & 0.025 \\
Language & 0.911 & 1.333 & 20.00 & 0.151 & 0.045 \\
Age & 0.913 & 1.880 & 14.00 & $0.026^{*}$ & 0.045 \\
Environment & 0.990 & 1.523 & 2.00 & 0.222 & 0.010 \\
Parent self-employed status & 0.996 & 0.600 & 2.00 & 0.550 & 0.004 \\
\hline
\end{tabular}

$\eta 2>0.25=$ large effect

* Statistically significant difference: $p<0.05$

Table 8: Differences in Entrepreneurship and Employability based on Year Level of Study

\begin{tabular}{lllllll}
\hline Item & 1 & 2 & 3 & 4 & $p$ & $\eta^{2}$ \\
\hline
\end{tabular}


Journal of Economics and Behavioral Studies (ISSN: 2220-6140)

Vol. 9, No. 1, pp. 56-68, February 2017

\begin{tabular}{lllllll}
\hline Entrepreneurship & 36.356 & 38.717 & 37.681 & 34.933 & $0.020^{*}$ & 0.040 \\
Employability & 24.792 & 23.255 & 23.536 & 25.533 & $0.009^{*}$ & 0.034 \\
\hline
\end{tabular}

$1=1^{\text {st }}$ year; $2=2^{\text {nd }}$; year; $3=3^{\text {rd }}$ year; $4=$ post-graduate $\eta 2>0,25=$ large effect

* Statistically significant difference: $p<0,05$

From Table 7 it is clear that a significant statistical difference exists between year level of study ( $F=4.040$; $p=0.001)$, race $(F=2.976 ; p=0.007)$, age $(F=1.880 ; p=0.026)$, and the two dependent variables (entrepreneurship and employability) within the sample. ANOVA analysis was performed to determine specific differences whenever statistical differences were found. The results of the ANOVA based on year level of study are given in Table 8.As seen from Table 8 it is clear that post-graduate students $(M=34.933)$ experience less differences than under-graduate students $(M=36.356 ; M=38.717 ; M=37.681)$ regarding the entrepreneurship dependent variable. This could indicate that they have a lower inclination to start their own business. A study done by Ekpoh and Edet (2011) found a positive relationship between education and entrepreneurial attitudes. This is in agreeance with the under-graduate' year level of study' groups but slightly contradicting to the post-graduate group which reported the lowest levels of entrepreneurial inclination. This could be due to the small sample size of the post-graduate group compared to the undergraduate groups' much larger sample sizes. Post-graduates also experience employability different from under-graduates with the post-graduate group reporting the highest level of employability $(M=25.533)$. This links to a study done by Stiwne and Alves (2010) stating that the employability of students is related to various characteristics of which include higher education levels. Enhancing education and adding entrepreneurship training could help students and young people to develop higher employability levels and increased intention to start a business (Bagheri \& Pihie, 2011).

Table 9: Difference in Entrepreneurship and Employability based on Race

\begin{tabular}{lllllll}
\hline Item & $\mathbf{1}$ & $\mathbf{2}$ & $\mathbf{3}$ & $\mathbf{4}$ & $\boldsymbol{P}$ & $\boldsymbol{\eta}^{2}$ \\
\hline Entrepreneurship & 38.391 & 39.222 & 32.286 & 36.383 & $0.006^{*}$ & 0.042 \\
Employability & 23.571 & 24.667 & 24.857 & 24.435 & 0.257 & 0.014 \\
\hline
\end{tabular}

1= Colored; $2=$ Indian/Asian; 3= White; 4= African black $\eta 2>0,25=$ large effect

* Statistically significant difference: $p<0,05$

From Table 9 it can be seen that Indian/Asian $(M=39.222)$, Coloured $(M=38.391)$ and African $(M=36.383)$ students experience a higher entrepreneurial inclination to start their own business than white students $(M=32.286)$ students. This is in contrast with research findings from a study conducted in the UK, indicating that a typical entrepreneur is white and male (Levine \& Rubinstein, 2013) and in this case, the white group of students reported the lowest level of entrepreneurial outlook and intention. Another study done by Herrington and Kew (2016) conducted only in South Africa, corresponds with the results of this study as it reported that Black Africans have higher entrepreneurial activity than White South Africans. A possible reason for this could be due to the South African policy regarding Black Economic Empowerment (BEE). BEE was introduced by the South African government to increase the number of Black Africans who own, manage and control the economy in order to decrease previous wrong-doings of apartheid and decrease inequalities (Department of Trade and Industry, 2011). This could affect white student's intention to start a business and their outlook on entrepreneurship.

Table 10: Difference in Entrepreneurship and Employability based on Age

\begin{tabular}{llllll}
\hline Item & $\mathbf{1}$ & $\mathbf{2}$ & $\mathbf{3}$ & $\boldsymbol{P}$ & $\eta^{2}$ \\
\hline Entrepreneurship & 37.064 & 37.891 & 40.667 & 0.253 & 0.009 \\
Employability & 24.573 & 23.305 & 23.333 & $0.020^{*}$ & 0.027 \\
\hline
\end{tabular}

$1=18-20$ years; $2=21-24$ years; $3=25$ years and older $\eta 2>0,25=$ large effect

* Statistically significant difference: $p<0,05$

Table 10 shows that students between the age group 18 and20 years' $(M=24.573)$ experience slightly higher employability levels than those older than 21 years $(M=23.305 ; M=23.333)$. Previous studies found that self-perceived employability and age are negatively correlated, and this could be due to younger people having high confidence and optimism levels and older people having a sense of accomplishment (Neilsen, 1999; Van der Heijden, 2002). These findings also link to the findings from this study as the youngest age 
group reported the highest employability levels. Van der Heijden et al. (2009) also found that age reduces the relationship between employability and career success from a supervisor and not a self-perceived point of view. It should be noted that studies by Nielsen (1999),Van der Heijden (2002) and Van der Heijden et al. (2009) focussed on people in larger ranged age groups and considering that the three groups' age difference in this study is only a few years apart having groups with larger age gaps may yield different results. In general, employability should increase with age due to increased education, skills and experience obtained.

\section{Conclusion and Recommendations}

The findings of this study suggest that students from this sample felt that entrepreneurship is a possible solution to the current youth unemployment issue in South Africa.Procter (2011) found a positive correlation between entrepreneurship skills and employability and although no correration between entrepreneurial outlook and employability was found in this study, these two concepts link well with each outher. The assumption can be made that even if students do not choose to start new businesses after graduation, providing entrepreneurial training may also improve employability as certain 'employer-friendly' traits are formed.Students from this study further felt that they do not have enough attributes that make them employable to existing businesses. Entrepreneurial awareness should be a fundamental topic raised at government level, spilling over to primary, secondary and higher educational levels. It is also important to provide such education for students who might not intend to apply to higher educational institutions or who cannot afford it.Developing and creating an entrepreneurialculturein the early stages of learning will add to the establishment of small businesses and improve employability. Many young people might not be inclined to start a new business, and they need to be employable to businesses. Special attention should be made to skills matching of jobs in demand and university offered degrees. A focus should also be placed on training young people to improve on certain job skills (Ibarraran et al., 2014). Implementing programmes addressing these issues could, in turn and to an extent, reduce the youth unemployment rate. Oladeleet al. (2011) found that unemployment is negatively correlated to entrepreneurial activity, thus meaning that the higher the unemployment rate, the lower the level of entrepreneurial activity. Thus, increasing the entrepreneurial support and activities could decrease the unemployment rate. These findings were also noted by Solomon et al. (2002).

The title of this article: "South Africa's youth unemployment dilemma: Whose baby is it anyway", explicitly poses the question as to who should be responsible for solving this rising problem. The answer is not that simple, however, with coordinated strategies from the government, assistance from the business sector and patience and commitment from the youth, solving or improving this problem is possible. Unemployment is a global phenomenon and problem, but, with suitable planning and intervention, it might be possible to reduce. A wider area of concern, however, is youth unemployment, and urgent interventions to resolve this issue is crucial. It is therefore of importance to address this problem by creating a foundation for young individuals and graduates to become more entrepreneurial and employable.Initiatives should not only be implemented in universities but also in schools as a large percentage of young people do not intend to join a higher education institution. Many internships and learnerships are available, but the availability of information lacks and is not distributed timeously. The following recommendations may assist with this problem if implemented in a positive manner:

- Students should be motivated and supported in developing their own business ideas or business plans while studying for their degrees.

- They must be taught to think "entrepreneurially".

- The content of educational programmes should be re-considered to create an entrepreneurial culture and "job-ready" and thus more employable students.

- Government and larger private corporations should create a supportive environment for entrepreneurs.

- Red-tape processes during the phases of starting a business should be relaxed, as stringent regulations and turnaround times make the task of starting a business very difficult.

- Specially-designed youth development programmes should be implemented to aid in developing more employable young people.

- Local businesses should become involved in, for example, providing practical training workshops.

- Internship programmes could assist in providing valuable knowledge. 
- Technical and practical skills should focus on in-training programmes.

- Businesses and other institutions should create mentorship programmes.

- Business incubators should be more active in their creation of young entrepreneurs and assist them with their new businesses.

- "After care" support for small businesses should be continued for a significant period after they start up, as many businesses fail within their first few years of operation.

- The government should initiate incentives for large companies to make use of local entrepreneurs in the supply chain and product sourcing.

\section{References}

Ambrish, D.R. (2014). Entrepreneurship development: an approach to economic empowerment of women. International Journal of Multidisciplinary Approach and Studies, 01(6), 224-232.

Athayde, R. (2012). The impact of enterprise education on attitudes to enterprise in young people: an evaluation study. Education and Training, 54(8/9), 709-725.

Awashti, D. \& Sebastian, J. (1996). Evaluation of entrepreneurship development programs. New Delhi: Sage Publications.

Bagheri, A. \& Pihie, Z.A.L. (2011). On becoming an entrepreneurial leader: a focus on the impacts of university entrepreneurship programs. American Journal of Applied Sciences, 8(9), 884-892.

Bhat, S.A. \& Khan, R.A. (2014). Entrepreneurship awareness programs (EAPs) impact on the promotion of youth entrepreneurship. Radix International Journal of Research in Social Sciences, 3(1), 1-12.

Blanchflower, D.G. \& Freeman, R. (2000). Youth employment and joblessness in advanced countries. Chicago, IL: University of Chicago Press.

BusinessTech. (2015). South Africa Unemployment: 1994-2015. Retrieved from http://businesstech.co.za/news/international/77737/south-africa-unemployment-1994-2015/

Choudhry, M., Marelli, E. \& Signorelli, M. (2013). Youth and total unemployment rate: the impact of policies and institutions. Rivista Internazionale di Scienze Sociali, 121, 63-86.

CIA World Fact Book. (2013). The world fact book. Retrieved from https://www.cia.gov/library/publications/the-world-factbook/fields/2129.html\#xx

CIA World Fact Book. (2016). The world fact book. Retrieved from https://www.cia.gov/library/publications/the-world-factbook/geos/xx.html

Daley, J. (2013). Are entrepreneurs born or made? Entrepreneur, September 19th pp 20-22.

Daniel, H. (2013). What are the causes of unemployment in Africa? Retrieved from http://www.hopeproject.org/development/what-are-the-causes-of-unemployment-in-africa/

De Feyter, M., Smulders, P. \& de Vroome, E. (2001). De inzetbaarheid van mannelijke en vrouwelijke werknemers. Kenmerken van invloed. Tijdschrift voor Arbeidsvraagstukken, 17(1), 47-59.

De Jongh, J.J., Meyer, N. \& Meyer, D.F. (2016). Perceptions of local businesses on the Employment Tax Incentive Act: The case of the Vaal Triangle Region. Journal of Contemporary Management, 13(1), 409-432.

Department of Government Communication and Information Systems. (2015). Understanding the root causes of unemployment, Insight Newsletter 1(13). Retrieved from http://www.gcis.gov.za/content/resourcecentre/newsletters/insight/issue13

Department of Trade and Industry. (2011). Based Black Economic Empowerment (B-BBEE) Management Development Programme. Retrieved from http://www.dti.gov.za/DownloadFileAction?id=667

Economist, (2013). Global youth unemployment, the lost generation. Retrieved from http://www.economist.com/blogs/freeexchange/2013/05/global-youth-unemployment

Ekpoh, U.I. \& Edet, A.O. (2011). Entrepreneurship education and career intentions of tertiary education students in Akwa Ibom and Cross River States, Nigeria. International Education Studies, 4(1), 172177.

El Mansour, B. \& Dean, J.C. (2016). Employability skills as perceived by employers and university faculty in the fields of Human Resource Development (HRD) for Entry Level Graduation Jobs. Journal of Human Resource Sustainability Studies, 4, 39-49.

Forrier, A. \& Sels, L. (2003). The concept employability: a complex mosaic. International Journal of Human Resource Development and Management, 3(2), 102-123. 
Hair, J., Anderson, R. F., Tatham, R. L. \& Black, W. C. (1998). Multivariate data analysis. Englewood Cliffs, NJ: Prentice Hall.

Heckman, J., Stixrud, J. \& Urzua, S. (2006). The effects of cognitive and non-cognitive abilities on labour market outcomes and social behaviour. Journal of Labour Economics, 24(3), 411-482.

Herrington, M. \& Kew, P. (2016). Global Entrepreneurship Monitor, South Africa Report 2015/16. Is South Africa heading for a meltdown? University of Cape Town, Cape Town South Africa.

Ibarraran, P., Ripani, L., Taboada, B., Villa, J.M. \& Garcia, B. (2014). Life skills, employability and training for disadvantaged youth: Evidence from a randomized evaluation design. IZA Journal of Labor \& Development, 3(10), 1-24.

ILO (International Labour Organisation). (2013). Global Employment Trends for Youth 2013. A generation at risk. International Labour Office: Geneva.

ILO (International Labour Organisation). (2016). Key Indicators of the Labor Market (KILM). Retrieved from http://www.ilo.org/global/statistics-and-databases/research-and-databases/kilm/lang-en/index.htm

Jones, G. (2013). Youth unemployment - is entrepreneurship the answer? Mail and Guardian: 5 March. Retrieved from http://www.financialmail.co.za/economy/2013/03/05/youth-unemployment---isentrepreneurship-the-answer.

Kane-Berman, J. (2015). There's no disguising SA's youth unemployment problem. Financial Mail. Retrieved from http://www.bdlive.co.za/opinion/columnists/2015/01/26/theres-no-disguising-sas-youthunemployment-problem

Karli, U. (2016). Adaptation and validation of self-perceived employability scale: An analysis of sports department students and graduates. Educational Research and Reviews, 11(8), 848-859.

Kirk, D. (2010). Causes of unemployment in South Africa. Retrieved fromhttp://twentythirdfloor.co.za/2010/12/01/causes-of-unemployment-in-south-africa/

Kroon, J. (2002). 'n Strategie vir entrepreneurskapsontwikkeling in Suid-Afrika. Tydskrif vir Geesteswetenskappe, 42(3), 215-223.

Levine, R. \& Rubinstein, Y. (2013). Smart and illicit: Who becomes an entrepreneurs and do they earn more? Working Paper 19276, Cambridge.

Mc Call, J.J. (1970). Economics of information and job search. The Quarterly Journal of Economics, 84, 113-126.

Meyer, N. \& Keyser, E. (2017a). Development of Entrepreneurial Scale for University student's intent to start a business. Working Paper.

Meyer, N. \& Keyser, E. (2017b). Development of Employability Scale for University students. Working Paper.

Meyer, N., Meyer, D.F. \& Molefe, K.N. (2016). Barriers to small informal business development and entrepreneurship: The case of the Emfuleni Region.Polish Journal of Management Studies, 13(1), 121-133.

Mincer, J. (1974). Schooling, experience and earnings. New York, NY: National Bureau of Economic Research.

Mlatsheni, C. \& Rospabé, S. (2002). Why is youth unemployment so high and unequally spread in South Africa? Cape Town: DPRU, University of Cape Town. (Working paper no. 02/65).

Mmesi, M. (2015). South Africa's youth unemployment problem: What we need to know. Retrieved from http://www.inonafrica.com/2015/05/26/south-africas-youth-unemployment-problem-what-weneed-to-know/

Mortensen, D.T. \& Pissarides, C.A. (1994). Job creation and job destruction in the theory of unemployment. The Review of Economic Studies, 61(3), 397-415.

National Treasury. (2011). Confronting youth unemployment: policy options for South Africa. Pretoria: Government Printer.

Nattrass, N. \& Walker, R. (2005). Unemployment and reservation wages in working-class Cape Town. South African Journal of Economics,73(3), 498-509.

Neilsen, J. (1999). Employability and workability amongst Danish employees. Experimental Ageing Research, 25, 393-397.

Nunnally, J. C. (1967). Psychometric theory. New York: McGraw-Hill.

O'Higgins, N. (2001). Youth unemployment and employment policy: a global perspective. Geneva, Switzerland: International Labour Organisation.

Odusegun, E. (2014.) Youth leader blames corruption for youth unemployment. Vanguard News. Retrieved from http://www.vanguardngr.com 
OECD. (2015). Small business, job creation and growth: Facts, obstacles and best practice. Retrieved from https://www.oecd.org/cfe/smes/2090740.pdf

Oladele, P.O., Akeke, N.I. \& Oladunjoye, O. (2011). Entrepreneurship Development: A Panacea for Unemployment Reduction in Nigeria. Journal of Emerging Trends in Economics and Management Sciences, 2(4), 251 - 256.

Oluwajodu, F., Blaauw, D., Greyling, L. \& Kleynhans, E.P.J. (2015). Graduate unemployment in South Africa: Perspectives from the banking sector. SA Journal of Human Resource Management, 13(1), 1-9.

Pallant, J. (2007). SPSS Survival Manual: A step by step guide to data analysis using SPSS for Windows. (3rd Ed.). New York: McGraw-Hill

Patel, B. \& Chavda, K. (2013). Rural entrepreneurship in India: Challenges and problems. International Journal of Advance Research in Computer Science and Management Studies, 1(2), 28-37.

Pettinger, T. (2012). A look at the economic reasons for high youth unemployment (16-25) in the UK. Retrieved from http://www.economicshelp.org/blog/517/economics/reasons-for-youthunemployment/

Procter, C. (2011). Employability and entrepreneurship embedded in professional placements in the business curriculum. Journal of Chinese Entrepreneurship, 3(1), 49 - 57.

Qenani, E., MacDougall, N. \& Sexton, C. (2014). An empirical study of self-perceived employability: Improving the prospects for student's employment success in an uncertain environment. Active Learning Higher Education, 15(3), 199-213.

Raguž, I.V. \& Matić, M. (2011). Students' perceptions and intentions towards entrepreneurship: The empirical findings from the University of Dubrovnik-Croatia. International Journal of Management Cases, Special issue: Circle Conference, 38-49.

Reserve Bank. (2015). Employment. Retrieved from http://www2.resbank.co.za /internet/Glossary.nsf/0/9028ea9be02366d342256b43002f51f5?OpenDocument.

Ryan, P. (2001). The school-to-work transition: a cross-national perspective. Journal of Economic Literature, 39(1), 34-92.

Sivvam, M. (2012). Women entrepreneurship: an Indian perspective. Saarbrücken, Germany: LAP Lambert.

Solomon, G.T., Duffy, S. \& Tarabishy, A. (2002). The State of Entrepreneurship Education in the United States: a Nationwide Survey and Analysis. International Journal of Entrepreneurship Education, 1(1), 1-22.

Statistics South Africa. (2016). Quarterly Labor Force Survey - Quarter 1: 2016 (P0211). May 2015. Pretoria: Government Printer.

Stiwne, E.E. \& Alves, M.G. (2010). Higher education and employability of graduates: will Bologna make a difference? European Education Research Journal, 9(1), 32-44.

Tabachnick, B. G. \& Fidell, L. S. (2001). Using multivariate statistics (4th Ed.). Boston, MA: Allyn \& Bacon.

Uddin, P.S.O. \& Uddin, O.O. (2013). Causes, effects and solutions to youth unemployment problems in Nigeria. Journal of Emerging Trends in Economics and Management Sciences, 4(4), 397-402.

Urzua, S. (2009). Report for the Inter-American Development Bank. Washington, DC: Inter-American Development Bank,

Van der Heijden, B. (2002). Pre-requisites to guarantee life-long employability. Personnel Review, 31, 44-61.

Van der Heijden, B.I.J.M., De Lange, A. H. \& Van der Heijde, E.D.C.M. (2009).Age effects on the employabilitycareer success relationship. Journal of Vocational Behavior, 74, 156-164.

W\&R SETA (Wholesale and Trade). (2016). Opportunities. Retrieved from http://www.wrseta.org.za/inner.aspx?section=2\&page $=235$

Webster, D. (2005). Long-term unemployment, the invention of 'hysteresis' and the misdiagnosis of structural unemployment in the UK. Cambridge Journal of Economics, 29(6), 975-995.

Wise-Quote. (2016). Franklin D. Roosevelt quotes. Retrieved from http://wise-quote.com/Franklin-DRoosevelt

World Bank. (2014). Unemployment, youth total (\% of total labor force ages 15-24). Retrieved from http://worldbank.org

World Bank. (2015). Unemployment, youth total (\% of total labor force ages 15-24). Retrieved from http://worldbank.org

World Economic Forum. (2014). Global risks 2014. $9^{\text {th }}$ ed. Geneva: World Economic Forum. 